\title{
Article \\ Combustion Melting Characterisation of Solid Fuel Obtained from Sewage Sludge
}

\author{
Dongju Kim ${ }^{1}{ }^{\mathbb{D}}$, Dong-kyoo Park ${ }^{1}$, Yong-taek Lim ${ }^{1}$, Soo-nam Park ${ }^{1}$, Yeong-Su Park ${ }^{1, *}$ and Kyunghyun Kim ${ }^{2}$ \\ 1 Plant Engineering Center, Institute for Advanced Engineering, Yongin 17180, Korea; \\ kimdongju@iae.re.kr (D.K.); parkdk@iae.re.kr (D.-k.P.); ytlim@iae.re.kr (Y.-t.L.); trackerdog@iae.re.kr (S.-n.P.) \\ 2 Department of Research Institute, Jinenertech Co., Ltd., Cheongyang 33317, Korea; \\ wilymaster7039@gmail.com \\ * Correspondence: yspark@iae.re.kr; Tel.: +031-330-7878
}

check for

updates

Citation: Kim, D.; Park, D.-k.; Lim, Y.-t.; Park, S.-n.; Park, Y.-S.; Kim, K. Combustion Melting Characterisation of Solid Fuel Obtained from Sewage Sludge. Energies 2021, 14, 805.

https://doi.org/10.3390/en14040805

Academic Editor: Changkook Ryu

Received: 7 January 2021

Accepted: 29 January 2021

Published: 3 February 2021

Publisher's Note: MDPI stays neutral with regard to jurisdictional claims in published maps and institutional affiliations.

Copyright: (c) 2021 by the authors. Licensee MDPI, Basel, Switzerland. This article is an open access article distributed under the terms and conditions of the Creative Commons Attribution (CC BY) license (https:// creativecommons.org/licenses/by/ $4.0 /)$.

\begin{abstract}
Solid fuelization technology can increase the heating value of sewage sludge such that it can be utilised as a fossil fuel substitutes. Reducing landfilling of bottom and fly ash resulting from heavy metals contained in sewage sludge is challenging. Hence, combustion melting technology (CMT), which can discharge bottom ash in the form of slag, has been proposed herein as an alternative to the conventional incineration technology. However, further research is required to improve the flowability of slag. Applicability of CMT for the stable treatment of heavy metals in the ash generated during the energisation of sewage sludge solid fuel has been reviewed. The change in the degree of fluidity was identified via a laboratory-scale fluidity measurement experiment following changes in melting temperature, mixing ratio of sewage sludge and sawdust, and basicity. The pouring index (PI) of sewage sludge solid fuel (pellet) was maintained at a level of about $60 \%$ at a basicity index of 0.8 . Based on the results, the slagging rates and volume reduction rates, exhaust gas analysis, and heavy metal elution characteristics under oxygen enrichment were derived from a 2 ton/day combustion melting pilot plant experiment; thereafter, the feasibility of combustion melting of sewage sludge solid fuel was determined.
\end{abstract}

Keywords: sewage sludge; slagging; pouring index; fluidity; basicity

\section{Introduction \\ 1.1. Sewage Sludge Generation and Treatment Status}

The amount of sewage sludge, a by-product of sewage treatment, is rapidly increasing worldwide owing to the increase in population; for example, China has recorded a $13 \%$ increase in sewage sludge over a six-year period since 2007. In South Korea, 11,219 tons of sewage sludge are produced daily, and this amount has rising since 2009, owing to an increase in population [1]. Sewage sludge incurs high treatment costs due to high moisture contents (73 84\%) as well as the heavy metals contained in ash [2-4]. Furthermore, as shown in Figure 1,50\% of the sewage sludge treatment in South Korea is handled under external consignment and metropolitan area treatments as of 2018, and fuelization technology accounts for $22 \%$ of total treatment [1].

Sewage sludge contains many organic substances, including microbial carcasses; therefore, it has high potential for use as fuel upon proper treatment. Generally, sewage sludge has an $80 \%$ moisture content before drying. The high heating value (HHV, dry basis) of sewage sludge solid fuel is approximately $85 \%(14.7 \mathrm{MJ} / \mathrm{kg})$, while that of wood pellets is slightly higher $(16.7 \mathrm{MJ} / \mathrm{kg})$ [2]. The sewage sludge generated in South Korea, as of 2018, amounts to 11,219 ton/day, from which the solid fuel produced is estimated to be 2493 ton/day, which is equivalent to 31,313 GJ/day based on the HHV. According to the status of sewage sludge fuelization in South Korea, the annual growth rate is approximately $10 \%$, from 2100 ton/day in 2016 to 2500 ton/day in 2018. As of 2018, the combined power 
generation by co-combustion of sewage sludge fuel is $405 \mathrm{GWh}$, or $0.175 \%$ of the coal-fired power generation $[5,6]$.

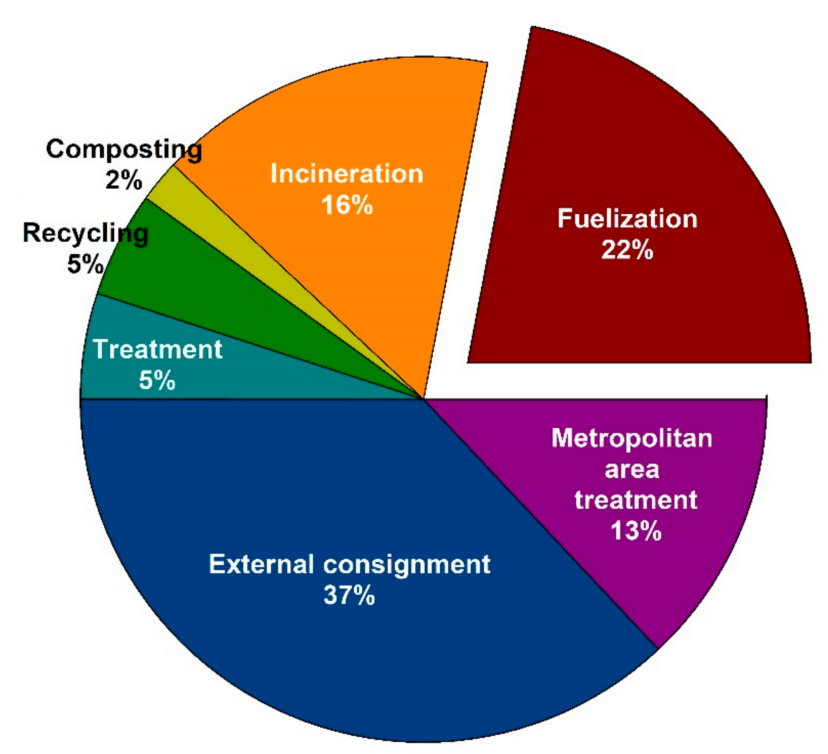

Figure 1. Sewage sludge treatment status in South Korea in 2018 [1].

Under the London Convention, marine pollution, caused by dumping of waste, has been prohibited. This, in conjunction with the enactment of the Act on the Promotion of The Development, Use and Diffusion of New and Renewable Energy, indicate that the demand for sewage sludge fuelization technology is expected to continually increase in the future.

\subsection{Energisation by Fuelization}

Various studies on the energisation of sewage sludge have been conducted in numerous countries. After pre-treatment, sewage sludge can be converted to solid fuel, biogas, biochar, bio-oil, and syngas through drying, anaerobic digestion, pyrolysis, and gasification technologies, or converted to heat or electric energy through direct combustion. The moisture content of sewage sludge is very high; therefore, direct combustion results in increased operating costs and reduced combustion efficiency owing to the use of auxiliary fuel $[4,7]$. Therefore, a solid fuelization process is required that involves the application of a drying technology for the removal of moisture through direct or indirect contact between sewage sludge and heat [4,7-10].

Sewage sludge solid fuelization technology can increase the HHV of sewage sludge as compared to that of fossil fuels, leading to the production of fuel that can be burned or cocombusted; the as-generated fuel can be used as a possible replacement of the conventional fossil fuels. This method can be used to produce solid fuel using only sewage sludge; however, in general, sawdust (a vegetable biomass) is mixed at $30-40 \%$ to the sewage sludge to avoid the formation of a glue-zone during the drying process. Additionally, sawdust acts as a binder in the pelletizing process, and increases the HHV of the solid fuel.

As discussed in Section 1.1., the use of sewage sludge fuel in South Korea has increased by $10 \%$ annually since 2016 , and currently, four thermal power plants that co-combust sewage sludge solid fuel are in operation. In 2019, a B city thermal power plant in Korea co-combusted approximately 8000 tons of solid fuel, containing mixed sawdust and sewage sludge [11]. Unlike wood pellets, the treatment costs of sewage sludge can be covered by local governments, thereby reducing the unit cost of solid fuel production [7]. Therefore, the demand for thermal power plants is expected to increase, and the costs incurred will be relatively low. 
However, owing to the presence of heavy metals in sewage sludge, large amounts of these metal contents in the fly and bottom ash generated during incineration have been reported [12]. Heavy metal content in the fly and bottom ash occurring during cocombustion with coal have also been reported to be problematic [13]. In addition, disposal costs have recently risen sharply due to limitations pertaining to the life spans of landfills, whereby additional locations for the treatment of incineration fly ash and bottom ash containing heavy metals need to be secured. For example, in the case of the landfill of incineration fly ash in South Korea, the treatment cost per ton has risen from $\$ 213$ to $\$ 420$. Hence, the combustion melting technology (CMT) of sewage sludge solid fuel has been proposed, which has the capacity to address pollution issues caused by heavy metals in ash, reduce ash weight, and allow for recycling to construction materials. However, the high cost of CMT operation with regard to sewage sludge has hindered the application of this technology. Nevertheless, a review of previous research on the melting of sewage sludge has revealed the aforementioned technology to be economic if the treatment cost per ton of sewage sludge is established at approximately $\$ 400$, making its application feasible.

\subsection{Combustion Melting Technology (CMT)}

CMT is considered an alternative solution to the problem of heavy metal discharge from conventional incineration methods. This technology involves pyrolysis, combustion, and melting processes. The synthetic gas generated by pyrolysis is burned in a combustion chamber, and the remaining solids are dissolved in a melting furnace to produce innoxious slag [14]. However, because high temperatures are required to melt the bottom ash, the energy consumption is high. In general, the melting temperature of sewage sludge ash was determined to be approximately $1200-1600{ }^{\circ} \mathrm{C}$ [8]. In addition, considering the need to use auxiliary burners for the smooth discharge of slag given the severe abrasion of refractories, research is required to improve the flowability of bottom ash [15]. In general, the melting temperature and flowability of ash are known to be affected by the basicity of the ash $\left(\mathrm{CaO} / \mathrm{SiO}_{2}\right)[16]$.

As discussed in Section 1.2., in the case of solid fuelization of sewage sludge, 30-40\% of sawdust is added to and mixed with the sewage sludge to avoid the formation of a glue-zone; thus, acting as a binder and increasing the HHV. Therefore, the effect of the amount of sawdust mixed on the melting temperature and flowability of sewage sludge solid fuel should be examined.

In addition, for combustion melting using auxiliary fuel, pure oxygen is generally used as an oxidant, and the melting temperature can be increased by lowering the heat loss; however, this increases the operating costs thereby lowering economic feasibility. Therefore, the effects on the melting of sewage sludge solid fuel and the emission of air pollutants under oxygen-enriched conditions should be examined.

\subsection{Evaluation of Slag Flowability by Fluidity Measurement}

The flowability of slag is closely related to the operating temperature of the furnace and the viscosity of the slag. An appropriate low level of viscosity is required for the smooth discharge of the slag in the melting furnace. Studies have demonstrated that a slag viscosity that ranges between $2.5 \mathrm{~Pa} / \mathrm{s}$ and $25.0 \mathrm{~Pa} / \mathrm{s}$ is appropriate for normal operation [17]. Therefore, measurement of the melting temperature and viscosity of the slag for the operation of the melting furnace is essential. However, these parameters are measured at high temperatures; this hinders their accurate measurements under laboratory conditions and makes the operation time-consuming and expensive. Owing to these challenges in the direct measurement of melting temperature and viscosity, indirect methods, such as prediction models and fluidity analysis, are sometimes used. In the case of coal, several melting temperature prediction models utilising the composition of ash have been developed and used, but no such prediction models have been developed for sewage sludge $[18,19]$. The development of such prediction models requires substantial analysis data on melting temperature. Another alternative is the fluidity analysis method, 
which is relatively simple and easily reproducible; this has been proposed in various studies $[8,11,16,19-23]$.

\subsection{Objectives of the Study}

This study seeks to examine the applicability of CMT to the stable treatment of heavy metals in the ash generated during the energisation process of sewage sludge solid fuel.

The purpose of this study is to specify the fluidity of the ash of the sewage sludge solid fuel and raw materials. In previous studies, there was a result that the change in basicity affects the melting temperature of the ash, and this study was conducted based on the hypothesis that there will be a change in fluidity according to the change in basicity. The research plan for this study is shown in Figure 2 below.

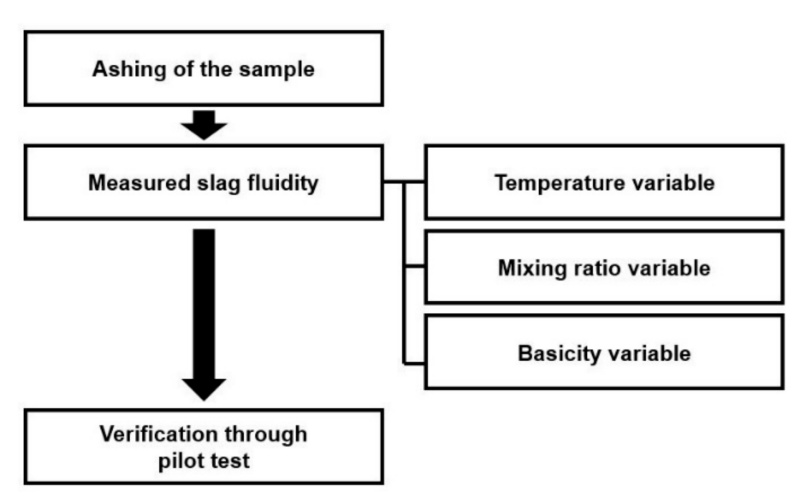

Figure 2. Schematic of the research plan.

Through laboratory-scale experiments, fluidity characteristics were analysed according to the mixing ratio of the sewage sludge and sawdust, melting temperature, and basicity of ash.

Thereafter, based on the laboratory-scale test results, we aimed to ascertain the applicability of the combustion melting of sewage sludge solid fuel under oxygen-enriched conditions using a 2 ton/day combustion melting pilot plant experiment.

\section{Materials and Methods}

\subsection{Sample Preparation and Properties}

Waste wood-based sawdust and sewage sludge were obtained from the sewage sludge solid fuel producer Jinenertech in South Korea for the experiment. The source of waste wood-based sawdust was a waste furniture and construction material processing company in Korea. Therefore, various types of wood were mixed, and also contained many impurities. The samples used in this study are shown in Figure 3.

To identify the physicochemical characteristics of the sewage sludge and sawdust, industrial analysis using the ASTM D 7582-15 test method was employed to measure moisture, combustible matter (volatile matter and fixed carbon), and ash [24]. Elemental analysis and calorific value assays were performed using the Quality Test and Analysis Method of Solid Refuse Fuel (2014) of the Republic of Korea to analyse the C, H, O, N, and $\mathrm{S}$ components and HHV [25]. In addition, EPA 3025 was used for heavy metal content analysis to determine the behaviour of these metals, and the Waste Processing Test Standard (2017) was applied to the heavy metal elution test [26,27]. 


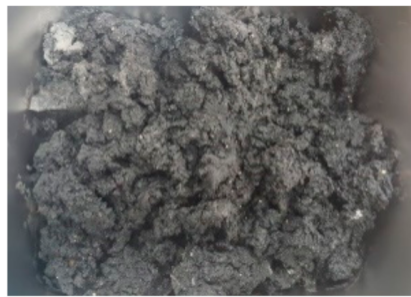

(a)

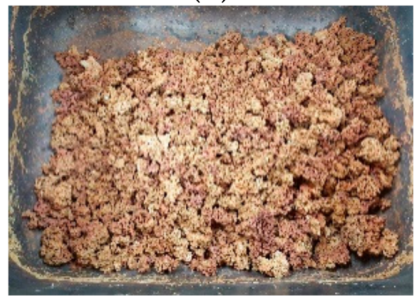

(c)

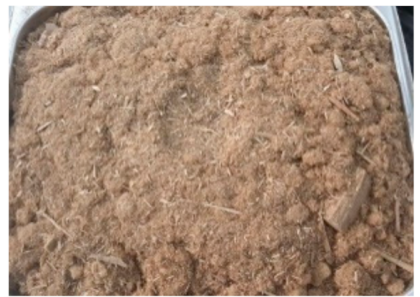

(b)

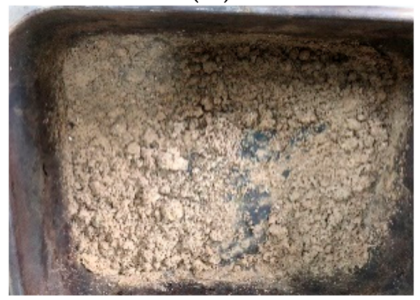

(d)

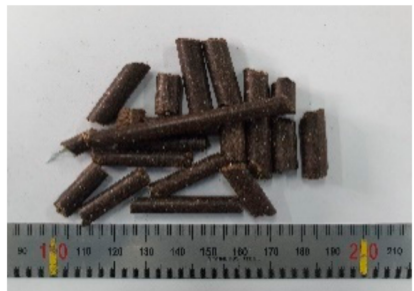

(e)

Figure 3. Images of samples: (a) sewage sludge, (b) sawdust, (c) sewage sludge ash, (d) sawdust ash, and (e) sewage sludge solid fuel pellets.

To identify the thermal reaction characteristics of the target samples, the TGA-DTA (thermo-gravimetric Analysis-Differential Thermal Analysis) was conducted using the simultaneous thermal analysis-mass spectrometer (STA-MS, NETZSCH STA-409).

To measure fluidity, sawdust and sewage sludge were first heated and ashed in an electric furnace. The ashing was conducted as follows in accordance with the Quality Test and Analysis Method of Solid Refuse Fuel: 1. Samples were placed in an electric furnace and the temperature was raised to $250{ }^{\circ} \mathrm{C}$ at $5{ }^{\circ} \mathrm{C} / \mathrm{min}$, and maintained for $60 \mathrm{~min}$, causing the evaporation of volatile matter; 2 . the temperature of the electric furnace was raised to $550{ }^{\circ} \mathrm{C}$ for $60 \mathrm{~min}$ and was maintained at this temperature for $120 \mathrm{~min}$ to combust the sawdust and sludge sample; 3 . if the sample was not completely combusted after one round, it was intensely heated again at $550{ }^{\circ} \mathrm{C}$ for complete combustion [28].

In addition, the sewage sludge solid fuel (pellet) input into the combustion melting pilot plant test under oxygen enrichment was produced at Jinenertech in South Korea by mixing sewage sludge and sawdust in a 68:32 ratios. This product is currently being supplied as a co-combustible fuel to D city and J city thermal power plants in South Korea.

\subsection{Pouring Index (PI) Test}

\subsubsection{Experimental Method}

The fluidity of ash was measured in accordance with the method presented by Kim et al. [16]. The size of the alumina boat used was $150 \mathrm{~L} \times 15 \mathrm{~W} \times 10 \mathrm{H}$, and the slope of the direction in which the sample was filled was maintained at $5^{\circ}$. To measure fluidity, the alumina boat was filled with the sample up to $20 \mathrm{~mm}\left(\mathrm{~L}_{0}\right)$ in the direction of the length, as shown in Figure 4. It was placed in the electric furnace, the temperature of which was raised by $10{ }^{\circ} \mathrm{C} / \mathrm{min}$ to the target temperature, and maintained for $15 \mathrm{~min}$. Then, the electric furnace power was turned off, temperature was cooled to below $1000^{\circ} \mathrm{C}$, the alumina boat was removed and cooled to atmospheric temperature, and the total length $(\mathrm{L})$ of the cooled 
sample was measured. The pouring index (PI) was calculated using the following formula, inputting the change in sample length before and after the experiment $[16,20,29]$.

$$
\mathrm{PI}\left(\text { pouring index, \%) }=\frac{\left(\mathrm{L}-\mathrm{L}_{0}\right)}{\mathrm{L}_{0}} \times 100\right.
$$

where $\mathrm{L}_{0}$ is the length of the initial sample, and $\mathrm{L}$ is the length of the slag that flowed down after melting. In this study, the same sample was measured four times to ensure the reliability of the data, and the average value of the measurements was used.
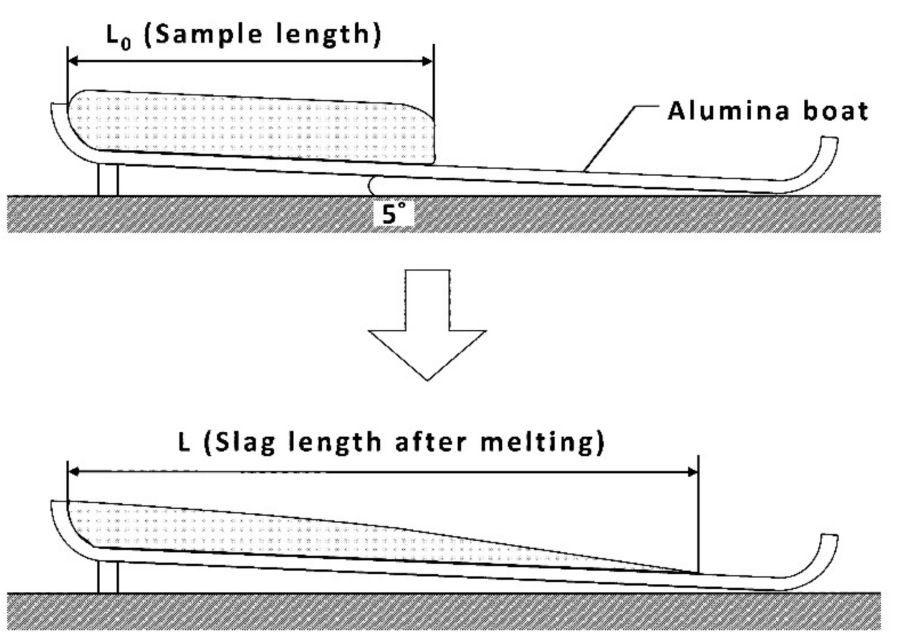

Figure 4. Schematic of pouring index experiment method [16].

\subsubsection{Experimental conditions}

To assess the degree of slag flowability in the combustion melting of sewage sludge solid fuel, the change in fluidity was measured according to the temperature of the sewage sludge, sawdust, and sawdust and sludge mixture, and basicity. The temperature was increased from $1200^{\circ} \mathrm{C}$ to $1300^{\circ} \mathrm{C}$ to confirm the changes in fluidity caused by temperature. In addition, the mixing ratio of sawdust was adjusted to observe the change in fluidity according to the degree of sawdust mixing. Finally, to determine the difference in fluidity according to basicity, fluidity was measured with basicity being controlled by adding $\mathrm{CaO}$ and $\mathrm{SiO}_{2}$ reagents to the sewage sludge and the sewage sludge pellets. Table 1 presents the conditions of the PI test experiment.

Table 1. Pouring index test experimental conditions.

\begin{tabular}{ccccc}
\hline & Sawdust Mixing Ratio (\%) & Temperature $\left({ }^{\circ} \mathbf{C}\right)$ & Reagents Added & Basicity (-) \\
\hline Test 1 & $0,32 *, 100$ & $1200,1250,1300$ & - & - \\
\hline Test 2 & $0,12.5,32 *, 80,90,100$ & 1300 & - & - \\
\hline Test 3 & - & 1300 & $\mathrm{SiO}_{2}, \mathrm{CaO}$ & $0.4-2.0$ \\
\hline
\end{tabular}

* Sawdust mixing ratio $32 \%$ for sewage sludge pellets.

\subsection{Pilot Plant Experiment}

\subsubsection{Experimental Method}

The 2 ton/day scale combustion melting pilot plant consists of solid fuel supply, combustion melting, slag discharge, and combustion gas cleaning facilities, as well as oxidant supply cleaning, water cooling and recirculation, and combustion gas emission systems. Figure 5 shows the composition of the pilot plant. The combustion melting furnace employs a fixed-bed type fuel melting method, comprising combustion, slagging, and homogenisation zones. Sewage sludge solid fuel is supplied in fixed quantities through 
rotary valves and conveyors on the side of the combustion furnace. Oxidants, a mixture of air and oxygen in a certain ratio, branch out as primary, secondary, and tertiary oxidants and are supplied to the reaction zone. The solid fuel ash is completely melted in the slagging and homogenisation zones and then moved to the slag quencher to be rapidly cooled by water. The slag is finally outputted through the conveyor discharge system.

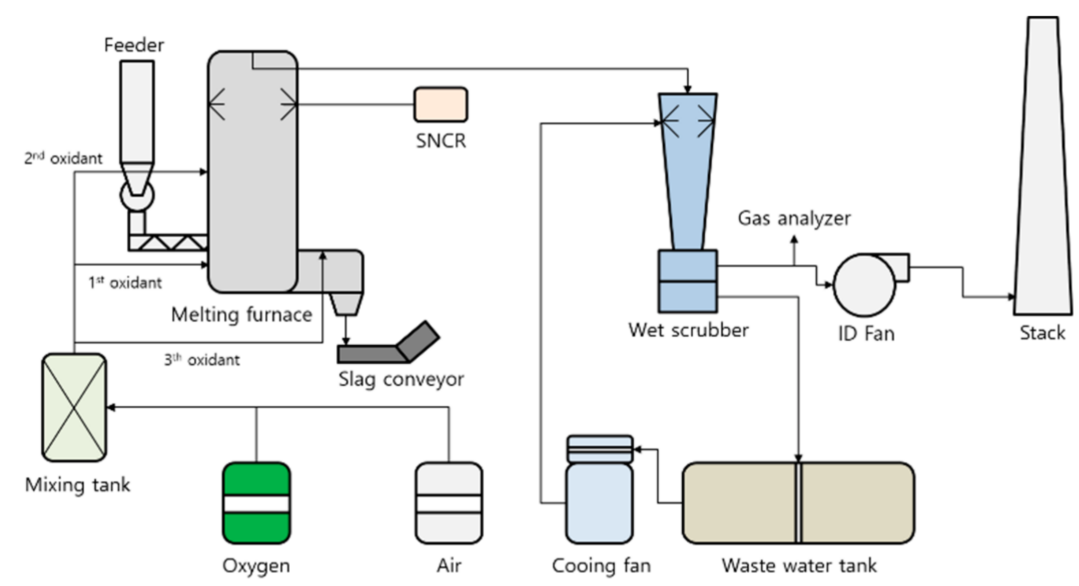

Figure 5. Schematic representation of the pilot-scale combustion melting plant components and processes. SNCR: selective non-catalytic reduction, ID fan: induced draft fan.

\subsubsection{Experimental Conditions}

The experimental conditions for the identification of the combustion melting characteristics of the sewage sludge solid fuel according to the oxygen enrichment ratio are presented in Table 2. The slagging and volume reduction rates were calculated based on the amount of slag generation, and innoxiousness was confirmed through the analysis of heavy metal content and elution of slag. In addition, the characteristics of air pollutant emissions were verified through an analysis of combustion exhaust gases.

Table 2. Pilot plant test experimental conditions.

\begin{tabular}{|c|c|c|c|c|c|c|c|c|}
\hline \multirow{2}{*}{ Test Condition } & \multirow{2}{*}{ Equivalent Ratio(-) } & \multicolumn{4}{|c|}{ Oxygen Enrichment Ratio (\%) } & \multicolumn{3}{|c|}{ Oxidant Distribution Ratio (\%) } \\
\hline & & 1st & 2nd & $3 r d$ & Total & $1 \mathrm{st}$ & 2nd & $3 r d$ \\
\hline & 1.4 & 70 & 70 & 100 & 80 & 80 & 15 & 5 \\
\hline
\end{tabular}

The slagging rate and the volume reduction rate are important design factors as an indicator of the raw material reduction rate in the combustion melting facility. These are expressed as follows:

$$
\begin{gathered}
\text { Slagging rate }(\%)=\frac{\text { Rate of slag production }(\mathrm{kg} / \mathrm{h})}{\text { Mass of sewage sludge ash fed }(\mathrm{kg} / \mathrm{h})} \times 100 \\
\text { Volume reduction rate }(\%)=\frac{\text { Slag volume }\left(\frac{l}{h}\right)+\text { Fly ash volume }\left(\frac{l}{h}\right)}{\text { Volume of solid fuel fed }\left(\frac{l}{h}\right)}
\end{gathered}
$$

\section{Results and Discussion}

\subsection{Analysis of the Physicochemical Characteristics}

Table 3 lists the physicochemical properties of sawdust, sewage sludge, and sewage sludge solid fuel. The ash content of sawdust was the highest at $19.54 \mathrm{wt} . \%$, and the ash content of sewage sludge was the lowest at $3.97 \mathrm{wt} . \%$. The HHV of the sewage sludge solid fuel was $14.94 \mathrm{MJ} / \mathrm{kg}$, and its sulphur component was $0.74 \mathrm{wt} . \%$. 
Table 3. Properties of sawdust, sewage sludge, and mixed solid fuel samples.

\begin{tabular}{ccccc}
\hline \multicolumn{1}{c}{ Properties } & & Sawdust & Sewage Sludge & \multicolumn{2}{c}{ Sludge Solid Fuel } \\
\hline \multirow{2}{*}{$\begin{array}{c}\text { Proximate Analysis } \\
\text { (Wet Basis, wt.\%) }\end{array}$} & Moisture & 12.98 & 82.55 & 7.48 \\
\cline { 2 - 5 } & Combustible & 67.49 & 13.49 & 73.72 \\
\hline $\begin{array}{c}\text { Proximate Analysis } \\
\text { (Dry Basis, wt.\%) }\end{array}$ & Ash & 19.54 & 3.97 & 78.80 \\
\cline { 2 - 5 } & Combustible & 77.55 & 79.68 \\
\hline $\begin{array}{c}\text { High Heating Value } \\
\text { (HHV; Dry Basis, MJ/kg) }\end{array}$ & Ash & 22.45 & 22.74 & 20.32 \\
\hline & - & 15.67 & 20.49 & 14.94 \\
\cline { 2 - 5 } & $\mathrm{C}$ & 41.48 & 44.69 & 36.95 \\
\hline $\begin{array}{c}\text { Ultimate Analysis } \\
\text { (Dry Basis, wt.\%) }\end{array}$ & $\mathrm{H}$ & 4.74 & 6.18 & 4.84 \\
\cline { 2 - 5 } & $\mathrm{O}$ & 28.71 & 20.07 & 25.61 \\
\hline
\end{tabular}

The oxide composition of the target sample was determined through X-ray fluorescence analysis (XRF) (Table 4). According to this analysis, $60 \%$ of sewage sludge ash consisted of $\mathrm{SiO}_{2}, \mathrm{Fe}_{2} \mathrm{O}_{3}$, and $\mathrm{CaO}$, and the basicity was 0.64 . Approximately $75 \%$ of the sawdust ash was composed of $\mathrm{SiO}_{2}, \mathrm{Fe}_{2} \mathrm{O}_{3}$, and $\mathrm{CaO}$, with a basicity of 0.86 . The greatest distinctions between sawdust ash and sewage sludge ash were that the $\mathrm{SiO}_{2}$ and $\mathrm{CaO}$ contents were high, but the $\mathrm{Fe}_{2} \mathrm{O}_{3}$ content was low, and above all, $\mathrm{P}_{2} \mathrm{O}_{5}$ was almost nonexistent. In addition, the basicity of solid fuel comprising sawdust and sewage sludge was 0.81 , which was higher than that of sewage sludge ash but comparable to that of sawdust.

Table 4. X-ray fluorescence analysis results of sawdust ash, sewage sludge ash, and sludge solid fuel ash.

\begin{tabular}{cccc}
\hline Component & $\begin{array}{c}\text { Sawdust Ash } \\
\text { (Dry Basis, wt.\%) }\end{array}$ & $\begin{array}{c}\text { Sewage Sludge Ash } \\
\text { (Dry Basis, wt.\%) }\end{array}$ & $\begin{array}{c}\text { Sludge Solid Fuel Ash } \\
\text { (Dry Basis, wt. \%) }\end{array}$ \\
\hline $\mathrm{SiO}_{2}$ & 33.2 & 24.0 & 30.5 \\
\hline $\mathrm{Fe}_{2} \mathrm{O}_{3}$ & 12.9 & 20.7 & 15.2 \\
\hline $\mathrm{CaO}$ & 28.4 & 15.4 & 24.6 \\
\hline $\mathrm{P}_{2} \mathrm{O}_{5}$ & 0.8 & 12.7 & 4.3 \\
\hline $\mathrm{Al}_{2} \mathrm{O}_{3}$ & 8.9 & 7.1 & 8.4 \\
\hline $\mathrm{SO}_{3}$ & 4.6 & 6.8 & 5.3 \\
\hline $\mathrm{CuO}$ & 0.1 & 3.3 & 1.0 \\
\hline $\mathrm{K}_{2} \mathrm{O}$ & 4.2 & 2.8 & 3.8 \\
\hline $\mathrm{ZnO}$ & 0.3 & 2.1 & 0.8 \\
\hline $\mathrm{MgO}$ & 1.6 & 1.1 & 1.5 \\
\hline $\mathrm{TiO}_{2}$ & 2.3 & 1.1 & 0.2 \\
\hline $\mathrm{NiO}_{\mathrm{Cr}} \mathrm{O}_{3}$ & 0.1 & 0.6 & 0.3 \\
\hline $\mathrm{CeO}$ & 0.2 & 0.5 & 0.2 \\
\hline $\mathrm{MnO}_{2}$ & $\mathrm{~N} / \mathrm{D}$ & 0.4 & 0.5 \\
\hline
\end{tabular}


Table 4. Cont.

\begin{tabular}{|c|c|c|c|}
\hline Component & $\begin{array}{c}\text { Sawdust Ash } \\
\text { (Dry Basis, wt.\%) }\end{array}$ & $\begin{array}{c}\text { Sewage Sludge Ash } \\
\text { (Dry Basis, wt.\%) }\end{array}$ & $\begin{array}{l}\text { Sludge Solid Fuel Ash } \\
\text { (Dry Basis, wt.\%) }\end{array}$ \\
\hline $\mathrm{PbO}$ & 0.1 & 0.3 & 0.2 \\
\hline $\mathrm{Na}_{2} \mathrm{O}$ & 0.3 & 0.2 & 0.3 \\
\hline $\mathrm{SnO}_{2}$ & $\mathrm{~N} / \mathrm{D}$ & 0.1 & 0.0 \\
\hline $\mathrm{BaO}$ & 0.2 & 0.1 & 0.2 \\
\hline $\mathrm{SrO}$ & 0.1 & 0.1 & 0.1 \\
\hline $\mathrm{WO}_{3}$ & $\mathrm{~N} / \mathrm{D}$ & 0.1 & 0.0 \\
\hline $\mathrm{Cl}$ & 1.0 & 0.1 & 0.7 \\
\hline $\mathrm{ZrO}_{2}$ & 0.0 & 0.1 & 0.0 \\
\hline $\mathrm{Co}_{2} \mathrm{O}_{3}$ & $\mathrm{~N} / \mathrm{D}$ & 0.0 & 0.0 \\
\hline $\mathrm{MoO}_{3}$ & $\mathrm{~N} / \mathrm{D}$ & 0.0 & 0.0 \\
\hline $\mathrm{Bi}_{2} \mathrm{O}_{3}$ & $\mathrm{~N} / \mathrm{D}$ & 0.0 & $\mathrm{~N} / \mathrm{D}$ \\
\hline $\mathrm{Ga}_{2} \mathrm{O}_{3}$ & $\mathrm{~N} / \mathrm{D}$ & 0.0 & $\mathrm{~N} / \mathrm{D}$ \\
\hline $\begin{array}{c}\text { Basicity } \\
\left(\mathrm{CaO} / \mathrm{SiO}_{2}\right)\end{array}$ & 0.86 & 0.64 & 0.81 \\
\hline
\end{tabular}

N/D: Not detected.

According to previous studies [16,23], the melting temperature of ash is lowered or raised by eutectic phenomena in accordance with the proportions of its components. Based on the results of the XRF analysis of sewage sludge and sawdust ash used in this study, a ternary system of $\mathrm{SiO}_{2}, \mathrm{CaO}$, and $\mathrm{Al}_{2} \mathrm{O}_{3}$ was prepared to predict the melting temperature of sewage sludge samples $[9,10,16]$. Among the components of sewage sludge ash, $\mathrm{CaO}, \mathrm{a}$ basic oxide, and $\mathrm{SiO}_{2}$, an acidic oxide, are the most commonly used components used to identify the melting properties, and the melting temperature is reported to be the lowest at a ratio of 1 for $\mathrm{CaO}$ and $\mathrm{SiO}_{2}$ [16,19]. As illustrated in Figure 6, sewage sludge is expected to move from the $1800{ }^{\circ} \mathrm{C}$ zone to the $1400{ }^{\circ} \mathrm{C}$ zone, and the melting temperature further increases to $1600{ }^{\circ} \mathrm{C}$ in the zone where $\mathrm{SiO}_{2}$ content increases.

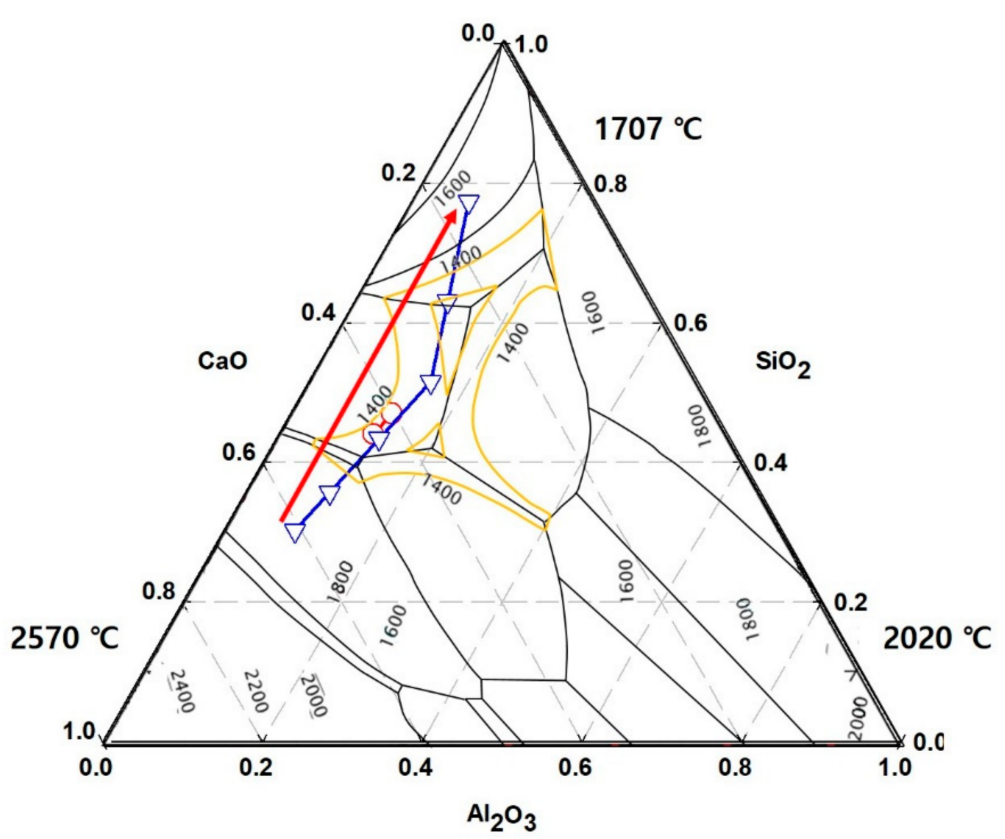

Figure 6. Melting temperatures at different basicity levels ( $\nabla$ : Sewage sludge, $\bigcirc$ : Sawdust). 


\subsection{Correlation between Ash Melting Temperature and Melting Indices}

In general, the melting temperature and flowability of ash are known to be affected by the inorganic composition of the ash, such as $\mathrm{CaO}, \mathrm{SiO}_{2}, \mathrm{Al}_{2} \mathrm{O}_{3}, \mathrm{Fe}_{2} \mathrm{O}_{3}$, and $\mathrm{MgO}$. Representative indices indirectly indicating the melting degree in accordance with the heretofore studied coal ash compositions are as follows [30].

$$
\begin{gathered}
\text { Base/Acid ratio }=\frac{\mathrm{CaO}}{\mathrm{SiO}_{2}} \\
\text { Silica ratio }=\frac{\mathrm{SiO}_{2}}{\mathrm{SiO}_{2}+\mathrm{Fe}_{2} \mathrm{O}_{3}+\mathrm{CaO}+\mathrm{MgO}} \\
\text { Iron/Calcium ratio }=\frac{\mathrm{Fe}_{2} \mathrm{O}_{3}}{\mathrm{CaO}} \\
\text { Silica/Alumina ratio }=\frac{\mathrm{SiO}_{2}}{\mathrm{Al}_{2} \mathrm{O}_{3}}
\end{gathered}
$$

Using these coal-based indices, the melting temperatures of the target samples in this study, namely sewage sludge, sawdust, and sewage sludge solid fuel ash, were predicted. First, using XRF and ash fusion temperature (AFT) data on coal ash by Guo et al. [31] and Namkung et al. [32], the correlation between the indices and the melting temperature was analysed, as illustrated in Figure 7. According to the analysis, the base/acid ratio demonstrates the highest correlation at an $r^{2}$ value of 0.7882 , while the $r^{2}$ values of the remaining three indices are very low.

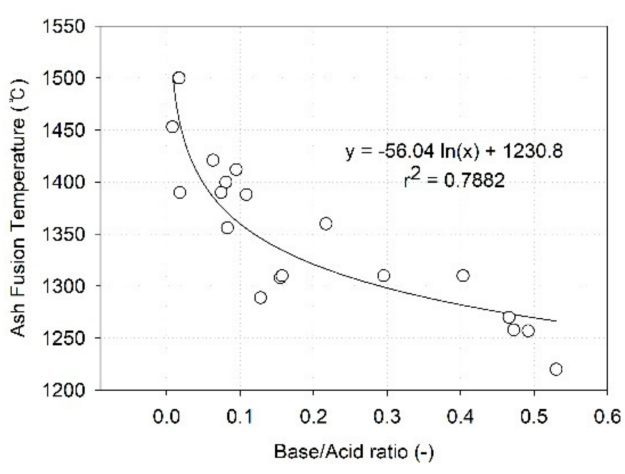

(a)

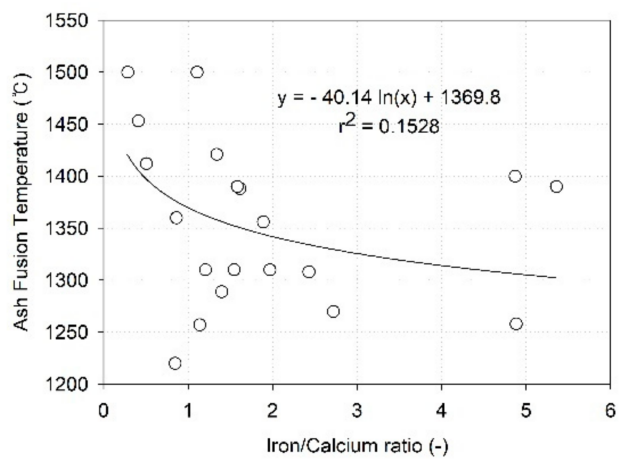

(c)

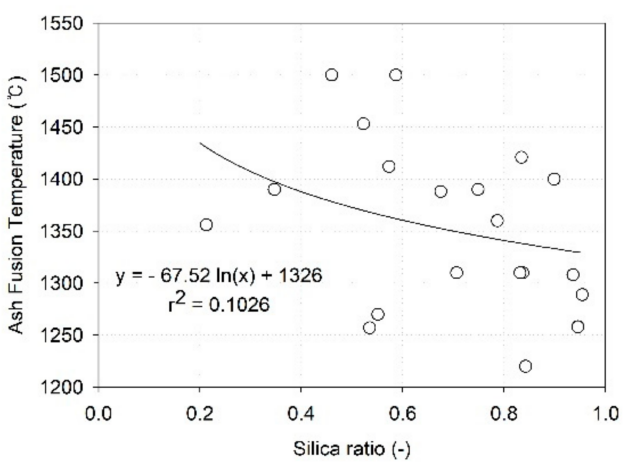

(b)

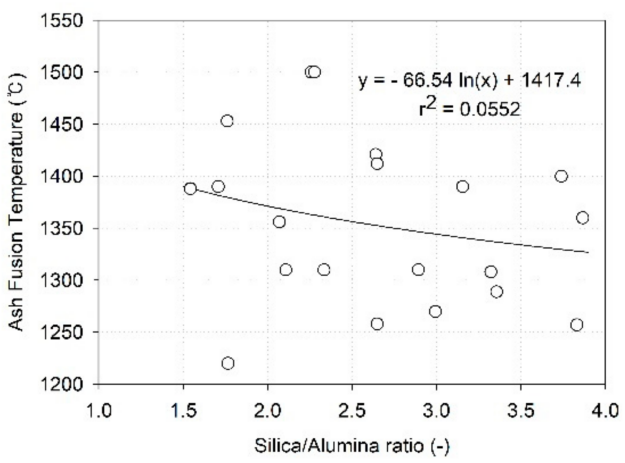

(d)

Figure 7. Correlation of coal melting indices: (a) base/acid ratio, (b) silica ratio, (c) iron/calcium ratio, (d) silica/alumina ratio.

Table 5 presents a comparison between the predicted melting temperatures using the base/acid ratio of each target sample and the actual analysed melting temperature. The predicted and analysed melting temperatures showed similar results for all samples. In 
this study, the base/acid ratio was used as an index to identify the fluidity of the target samples, including sewage sludge.

Table 5. Comparison of the melting temperature prediction and analysis results.

\begin{tabular}{ccc}
\hline & $\begin{array}{c}\text { Expected Melting Temperature } \\
\left({ }^{\circ} \mathbf{C}\right)\end{array}$ & $\begin{array}{c}\text { Ash Fusion Temperature } \\
\left({ }^{\circ} \mathbf{C}\right)\end{array}$ \\
\hline Sewage Sludge & 1255.6 & 1260 \\
\hline Sawdust & 1239.5 & 1270 \\
\hline Sludge Solid Fuel & 1242.8 & 1290 \\
\hline
\end{tabular}

\subsection{Thermo-Gravimetric Analysis-Differential Thermal Analysis}

TGA-DTA analysis results are shown in Figure 8. Under a nitrogen atmosphere, the temperature was raised to $1500^{\circ} \mathrm{C}$ at $10^{\circ} \mathrm{C} / \mathrm{min}$ to measure the change in mass and heating value. The melting of the sewage sludge started at $985^{\circ} \mathrm{C}$, progressed rapidly from $1159^{\circ} \mathrm{C}$, and it was completed at $1300^{\circ} \mathrm{C}$. The melting of the sawdust began at $796^{\circ} \mathrm{C}$, lower than that of sewage sludge, and progressed in earnest from $1089^{\circ} \mathrm{C}$. The melting of the sewage sludge solid fuel began at $1004{ }^{\circ} \mathrm{C}$, the melting progressed rapidly from $1100{ }^{\circ} \mathrm{C}$, and it was completed at $1350^{\circ} \mathrm{C}$.

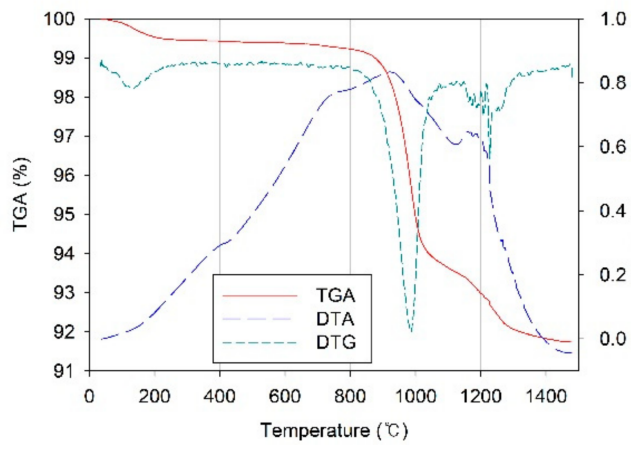

(a)

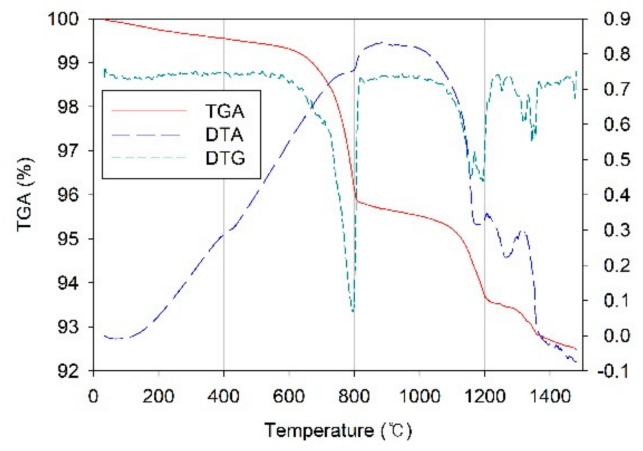

(b)

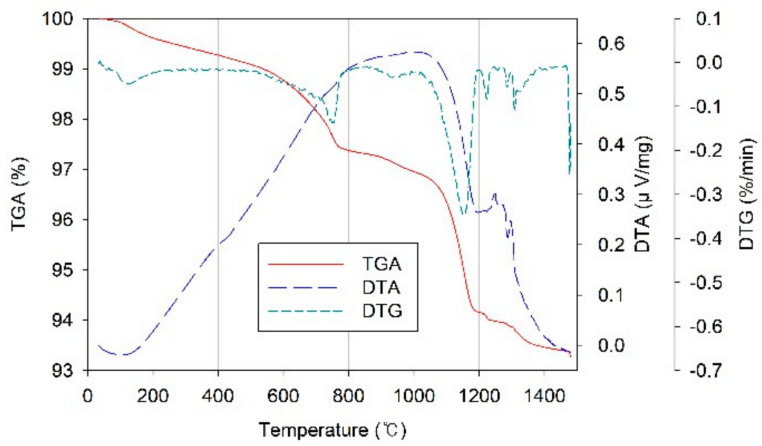

(c)

Figure 8. Results of thermo-gravimetric analysis (TGA) — differential thermal analysis (DTA), derivative thermo gravimetry(DTG): (a) sewage sludge, (b) sawdust, (c) sludge solid fuel.

\subsection{Results of the Pouring Index Test}

\subsubsection{Pouring Index as a Function of Temperature}

The effects of the reaction temperature on the PIs of sewage sludge, sawdust, and their mixture (68:32) were analysed (Figure 9 and Table 6). The reaction temperatures were at 1200,1250 , and $1300{ }^{\circ} \mathrm{C}$. The sewage sludge showed the highest PI throughout its melting temperature range, and the PIs of all three samples demonstrated a tendency to increase with an increase in the reaction temperature. The reaction temperatures of sewage 
sludge, sawdust, and their mixture satisfying the fluidity standard of $60 \%$ for normal discharge of slag were approximately 1230,1300 , and $1300{ }^{\circ} \mathrm{C}$, respectively. The PIs of samples of sawdust mixed in sewage sludge were lower than those of the sewage sludge, and comparable to those of sawdust. In other words, mixing sawdust with sewage sludge yielded negative results with respect to ash PIs.

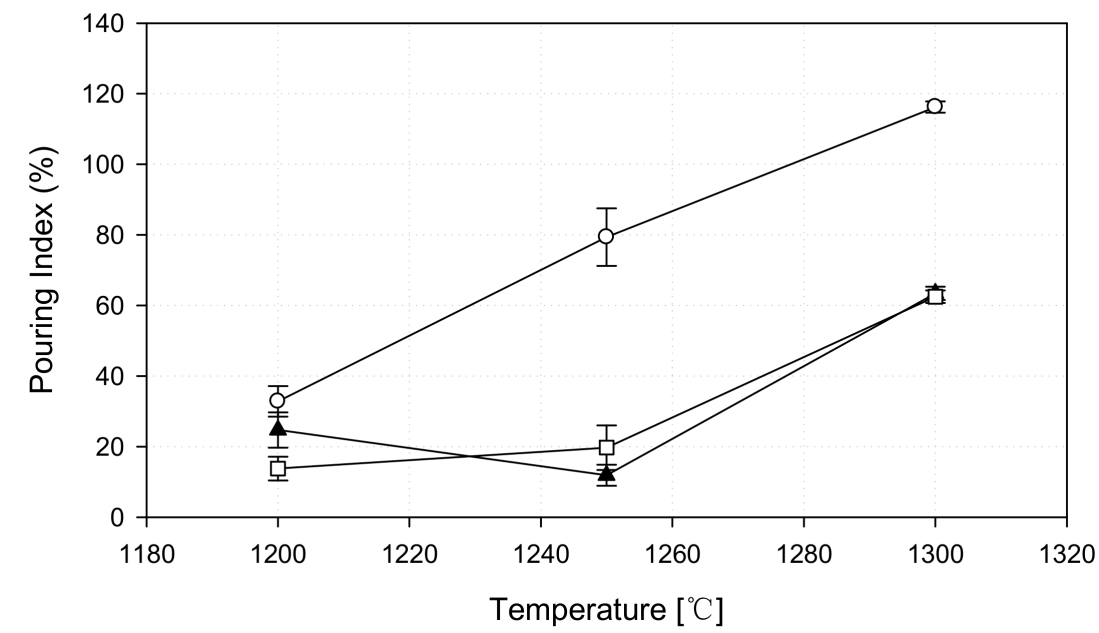

Figure 9. Results of pouring index at different temperatures $(\bigcirc$ : Sewage sludge, $\mathbf{\Delta}$ : Sawdust, $\square$ : Mixture).

Table 6. Images of pouring test results.

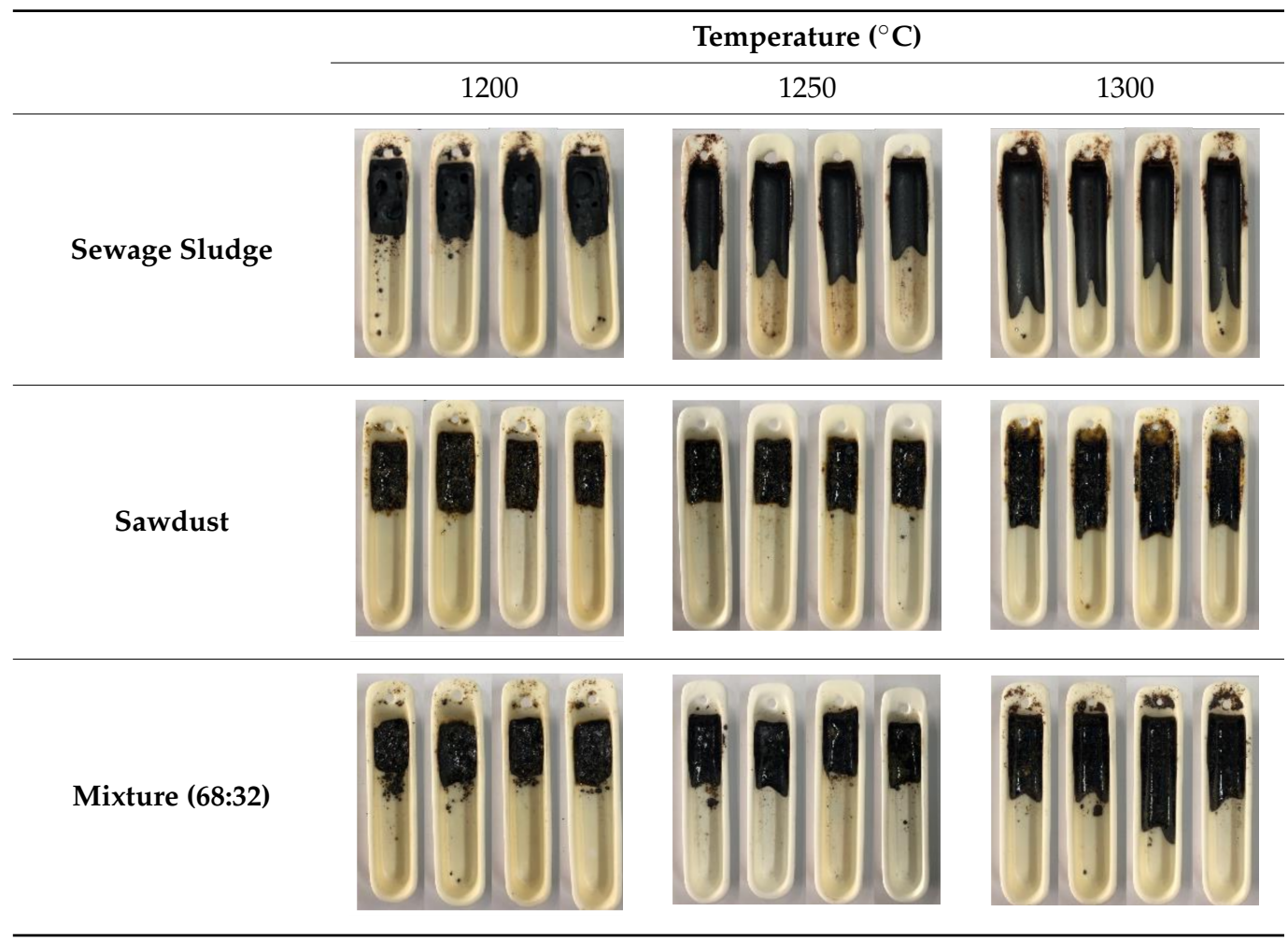

\subsubsection{Pouring Index as a Function of Sawdust Mixing Ratio}

The effect of the sawdust mixing ratio on the PI of sewage sludge solid fuel was analysed (Figure 10). The mixing ratio of sawdust was set at 12.5, 32, 80, and 90\%, at a reaction temperature of $1300{ }^{\circ} \mathrm{C}$. As the mixing ratio of sawdust increased, the basicity gradually increased while the PI decreased. When the mixing ratio of sawdust exceeded $32 \%$, little 
change in PI was observed. The PI of sewage sludge solid fuel was expected to remain at approximately $60 \%$ at a basicity index of 0.8 or higher. Therefore, if sawdust was mixed at a ratio that exceeded $32 \%$ to avoid the glue-zone, thus increasing pellet formability and HHV, no significant issue was anticipated in the operation of the combustion melting system.

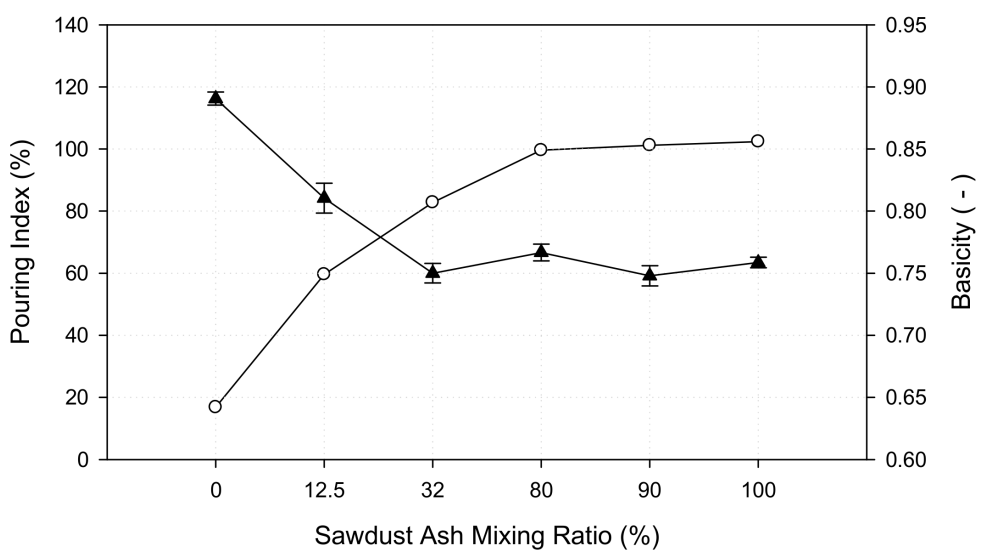

Figure 10. Pouring index at various sawdust mixing ratios ( $\mathbf{\Delta}$ : Pouring index, $\bigcirc$ : Basicity).

\subsubsection{Pouring Index as a Function of Basicity}

The effect of basicity on the PI of sewage sludge and sewage sludge solid fuel was analysed, as shown in Figure 11. Based on the results of the XRF analysis of the ash, the basicity of the sewage sludge and mixture (68:32) was 0.64 and 0.81 , respectively, and was adjusted by mixing $\mathrm{SiO}_{2}$ and $\mathrm{CaO}$ in the target sample according to specific ratios. The temperature was set at $1300^{\circ} \mathrm{C}$ because a PI of $100 \%$ or higher was yielded at $1300^{\circ} \mathrm{C}$. When the basicity was adjusted using $\mathrm{SiO}_{2}$ and $\mathrm{CaO}$ reagents in the sewage sludge, the PI tended to be lower than that of the original sample regardless of the basicity, indicating that basicity had no effect on the PI. However, the PI exhibited a slight increase at the point where the basicity increased from 1.5 to 2.0. In addition, in the case of the mixture (68:32), the PI tended to reduce sharply as the basicity dropped below 0.5 , which is distinct from the effect of the mixing ratio of sawdust on the basicity index, as illustrated in Figure 10. Inorganic materials other than $\mathrm{CaO}$ contained in the sawdust ash are believed to affect the change in fluidity. In addition, according to previous studies $[8,16,23,33]$, the increase in fluidity when sawdust is added to adjust the basicity is attributed to the melting temperature being lower than that of a single substance if an inorganic material contained in the ash forms a eutectic compound.

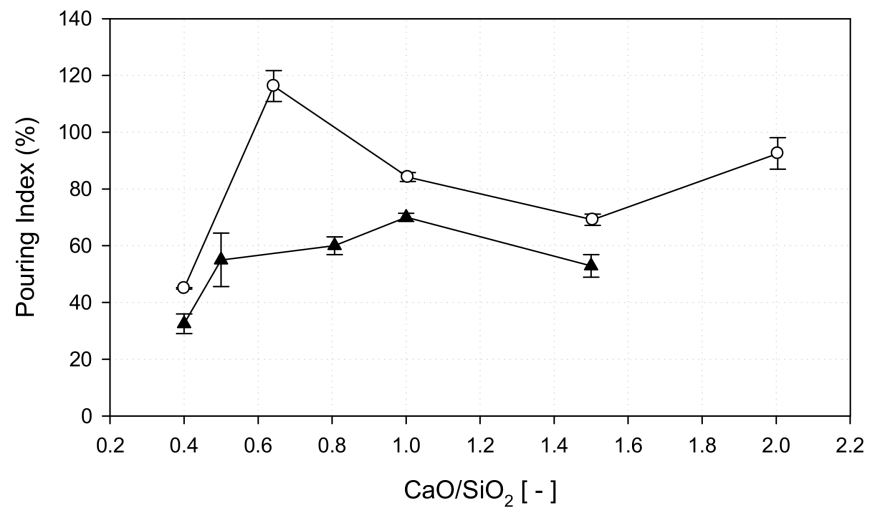

Figure 11. Results of pouring indices according to basicity ( $\bigcirc$ : Sewage sludge, $\mathbf{\Lambda}$ : Mixture). 


\subsection{Results of the Pilot Plant Test}

\subsubsection{Slag Exhaust Characteristics}

A pilot test was conducted to identify the characteristics of combustion melting of sewage sludge solid fuel under oxygen-enriched conditions. Based on the results of the measurement of the PI, solid fuel of the sewage sludge with a sawdust ratio of $32 \%$ was used for the pilot plant operation, at a reaction temperature of $1300^{\circ} \mathrm{C}$ where the pouring index was above $60 \%$. A slight change in the operating temperature profile of the slagging zone during the test was observed in the initial stage of the operation, but the temperature distribution was stable across a range of $1249-1374{ }^{\circ} \mathrm{C}$, throughout all the operational stages of the plant. The average operating temperature $\left(1328^{\circ} \mathrm{C}\right)$ was sufficient for the stable melting of the ash.

The weight of the slag produced from the slag quencher installed at the bottom of the combustion melting furnace was measured, the result of which is shown in Figure 12. The weight of the slag fluctuated with the operation time, but the accumulated slag discharge steadily increased. The average discharge rate of slag for all operational stages was 9.8 $\mathrm{kg} / \mathrm{h}$, which corresponded to $18.0 \%$ of the sewage sludge feed rate of $54.4 \mathrm{~kg} / \mathrm{h}$. Similarly, the ash content of the sewage sludge solid fuel was $18.8 \%$. In other words, the melting of the ash and the discharge of slag proceeded very smoothly.

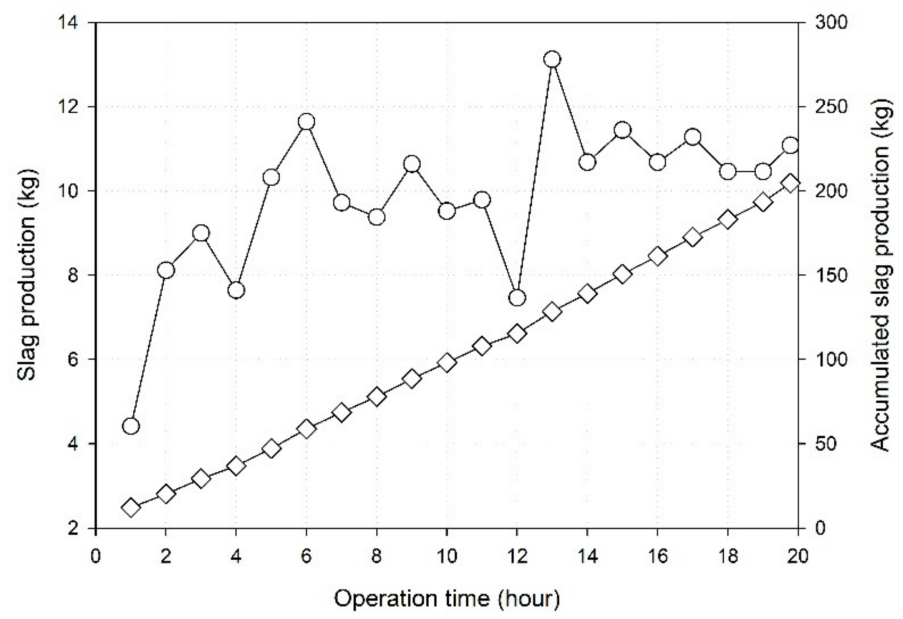

Figure 12. Pilot plant slag production mass $(\bigcirc$ : Slag production, $\diamond$ : Accumulated slag production).

XRF analysis results for the basicity of the slag produced are presented in Table 7. The composition of the slag produced was similar to the results of the XRF analysis of the sewage sludge solid fuel. The average basicity was 0.88 , and the PI of the slag at $1328^{\circ} \mathrm{C}$, the average melting temperature of the pilot plant, was deemed to have remained at $60 \%$.

The slagging and volume reduction rates of the produced slag were evaluated, and the results are shown in Figure 13. The slagging rates during all the operation stages ranged from $61.85 \%$ to $97.33 \%$, and the average slagging rate was $88.03 \%$. In addition, the slag volume reduction rate ranged between $87.29 \%$ and $91.63 \%$, and was $88.93 \%$ on average. The apparent density of slag was $1.45 \mathrm{~kg} / \mathrm{cm}^{3}$, which is approximately 1.9 -fold higher than the apparent density of the common bottom ash $\left(0.75 \mathrm{~kg} / \mathrm{cm}^{3}\right)$ produced during combustion. From these results, the volume reduction rate through combustion melting was expected to be approximately two times higher than that through regular combustion, which may contribute to the extension of the life span of landfills by preventing the landfill of bottom ash through combustion. 
Table 7. X-ray fluorescence analysis results of slag.

\begin{tabular}{|c|c|c|c|c|c|}
\hline Component & $\begin{array}{c}\text { Slag \#1 } \\
\text { (Dry Basis, } \\
\text { wt. } \% \text { ) }\end{array}$ & $\begin{array}{c}\text { Slag \#2 } \\
\text { (Dry Basis, } \\
\text { wt. \%) }\end{array}$ & $\begin{array}{c}\text { Slag \#3 } \\
\text { (Dry Basis, } \\
\text { wt. \%) }\end{array}$ & $\begin{array}{c}\text { Slag \#4 } \\
\text { (Dry Basis, } \\
\text { wt. } \% \text { ) }\end{array}$ & Average \\
\hline $\mathrm{SiO}_{2}$ & 24.36 & 26.06 & 25.64 & 25.78 & 25.46 \\
\hline $\mathrm{Fe}_{2} \mathrm{O}_{3}$ & 24.47 & 17.22 & 19.18 & 19.58 & 20.11 \\
\hline $\mathrm{CaO}$ & 19.98 & 22.72 & 23.96 & 23.08 & 22.43 \\
\hline $\mathrm{P}_{2} \mathrm{O}_{5}$ & 5.60 & 4.57 & 4.84 & 5.45 & 5.12 \\
\hline $\mathrm{Al}_{2} \mathrm{O}_{3}$ & 12.12 & 13.47 & 13.10 & 13.09 & 12.95 \\
\hline $\mathrm{SO}_{3}$ & 0.30 & 0.16 & 0.06 & 0.30 & 0.20 \\
\hline $\mathrm{CuO}$ & 0.74 & 0.40 & 0.29 & 0.31 & 0.44 \\
\hline $\mathrm{K}_{2} \mathrm{O}$ & 1.32 & 1.65 & 1.98 & 2.50 & 1.86 \\
\hline $\mathrm{MgO}$ & 2.28 & 2.62 & 2.60 & 2.56 & 2.52 \\
\hline $\mathrm{TiO}_{2}$ & 1.52 & 1.72 & 1.99 & 1.83 & 1.76 \\
\hline $\mathrm{NiO}$ & 0.33 & 0.07 & 0.10 & 0.10 & 0.15 \\
\hline $\mathrm{Cr}_{2} \mathrm{O}_{3}$ & 3.88 & 6.01 & 2.88 & 2.65 & 3.86 \\
\hline $\mathrm{MnO}$ & 0.36 & 0.44 & 0.39 & 0.32 & 0.38 \\
\hline $\mathrm{Na}_{2} \mathrm{O}$ & 2.24 & 2.04 & 2.04 & 1.96 & 2.07 \\
\hline $\mathrm{SrO}$ & 0.21 & 0.25 & 0.25 & 0.18 & 0.22 \\
\hline $\mathrm{ZrO}_{2}$ & 0.29 & 0.60 & 0.72 & 0.30 & 0.48 \\
\hline $\begin{array}{c}\text { Basicity } \\
\left(\mathrm{CaO} / \mathrm{SiO}_{2}\right)\end{array}$ & 0.82 & 0.87 & 0.93 & 0.90 & 0.88 \\
\hline
\end{tabular}

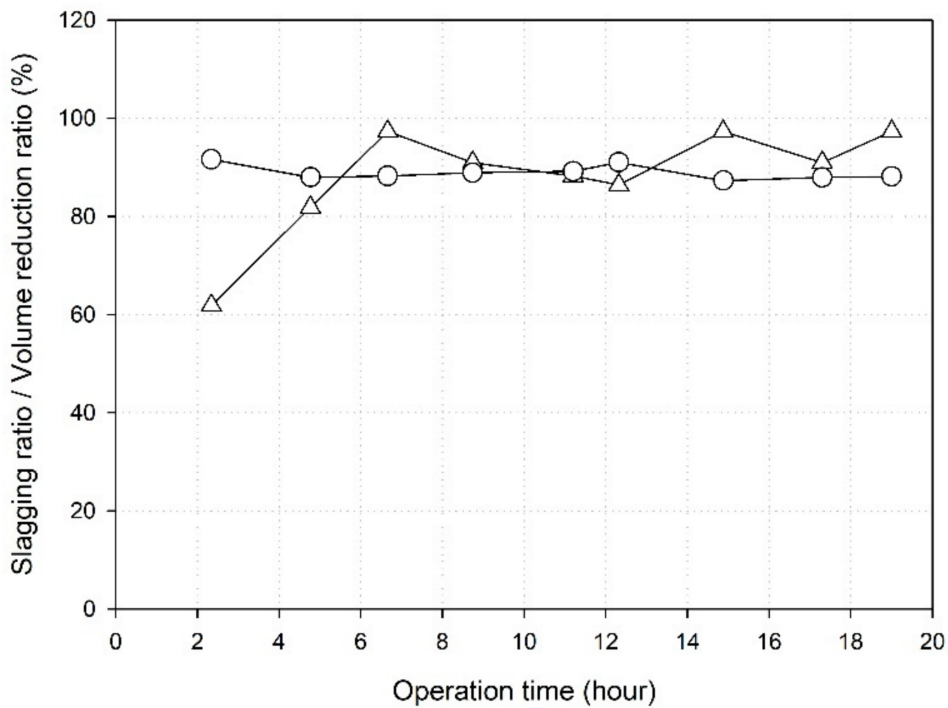

Figure 13. Results of slagging and volume reduction ratio $(\triangle$ : Slagging Ratio, $\bigcirc$ : Volume reduction ratio).

\subsubsection{Air Pollutants in the Exhaust Gas}

To guarantee the economic feasibility of the combustion melting process using sewage sludge solid fuel, the operation was performed under conditions of oxygen enrichment at $80 \%$, and the air pollutants present in the generated combustion gases were analysed. From Table 8, it is evident that the values of $\mathrm{CO}$ and $\mathrm{SO}_{2}$ satisfied the permissible air pollution emission criteria of the Republic of Korea, but $\mathrm{NO}_{\mathrm{x}}$ averaged at a relatively high level of 
$853 \mathrm{ppm}$. Nitrogen in the air supplied for the oxygen-enriched operation was converted to thermal $\mathrm{NO}_{\mathrm{x}}$ at the high temperature of $1300{ }^{\circ} \mathrm{C}$. To reduce the $\mathrm{NO}_{\mathrm{x}}$ emissions contained in the exhaust gases, facilities enabling selective non-catalytic reduction (SNCR) and selective catalytic reduction (SCR) may be installed for air pollution prevention. The efficiency of SNCR generally ranges from $50 \%$ to $60 \%$, while that of SCR ranges from $85 \%$ to $90 \%$. However, when SNCR and SCR are installed in the combustion melting system under an oxygen enrichment condition of $80 \%$, the atmospheric emission concentration of $\mathrm{NO}_{\mathrm{x}}$ is estimated to be up to $34 \mathrm{ppm}$, which does not satisfy the $30 \mathrm{ppm}$ standard for permissible air pollution emission criteria of South Korea, requiring further efforts to reduce $\mathrm{NO}_{\mathrm{x}}$.

Table 8. Air pollutant concentrations in the exhaust gas.

\begin{tabular}{cccccccccccc}
\hline \multicolumn{3}{c}{$\mathrm{CO}_{\mathbf{2}}(\mathbf{\%})$} & \multicolumn{4}{c}{$\mathrm{CO}(\mathrm{ppm})$} & \multicolumn{3}{c}{$\mathrm{NO}_{\mathbf{x}}(\mathbf{p p m})$} & \multicolumn{3}{c}{$\mathrm{SO}_{\mathbf{2}}(\mathbf{p p m})$} \\
\hline Max. & Min. & Avg. & Max. & Min. & Avg. & Max. & Min. & Avg. & Max. & Min. & Avg. \\
\hline 62 & 31 & 41 & 60 & 0 & 2 & 1032 & 677 & 853 & 0 & 0 & 0 \\
\hline
\end{tabular}

\subsubsection{Heavy Metal Analysis}

Heavy metal content and elution analyses were conducted to identify the behaviour of heavy metals in slag produced during the combustion melting process of sewage sludge solid fuel. Six heavy metals were analysed: $\mathrm{Pb}, \mathrm{Cd}, \mathrm{Cu}, \mathrm{As}, \mathrm{Cr}$, and $\mathrm{Hg}$ (Table 9). Five heavy metals (excluding $\mathrm{Cd}$ ) were detected in the eluted solution of fly ash from the pilot plant; in the case of slag, no metals were eluted, except for $\mathrm{Cu}$. These results confirmed that the slag of the sewage sludge solid fuel retained heavy metals.

Table 9. Heavy metal concentrations in various sludge, slag, and ash samples.

\begin{tabular}{|c|c|c|c|c|c|c|c|}
\hline Sample & Unit & $\mathrm{Pb}$ & $\mathrm{Cd}$ & $\mathrm{Cu}$ & As & $\mathrm{Cr}$ & $\mathrm{Hg}$ \\
\hline \multicolumn{8}{|c|}{ Content Analysis } \\
\hline $\begin{array}{l}\text { Sludge Solid } \\
\text { Fuel Ash }\end{array}$ & $\mathrm{mg} / \mathrm{kg}$ & 711.57 & 28.24 & $6,737.77$ & 24.77 & 1137.24 & 0.07 \\
\hline \multicolumn{8}{|c|}{ Leaching Analysis } \\
\hline Fly Ash & \multirow{2}{*}{$\mathrm{mg} / \mathrm{L}$} & 0.07 & $\mathrm{~N} / \mathrm{D}$ & 0.593 & 0.638 & 0.933 & 0.006 \\
\hline Slag & & $\mathrm{N} / \mathrm{D}$ & $\mathrm{N} / \mathrm{D}$ & 0.213 & $\mathrm{~N} / \mathrm{D}$ & $\mathrm{N} / \mathrm{D}$ & $\mathrm{N} / \mathrm{D}$ \\
\hline
\end{tabular}

\section{Conclusions}

This study reviewed the applicability of CMT in the energisation of sewage sludge solid fuel. The characteristics of slagging, according to temperature, mixing ratio of sawdust, and ash basicity were analysed using the basicity index and PI.

1. The PI of the mixture was lower than that of sewage sludge, and yielded results that were similar to those of sawdust, indicating that the sewage sludge solid fuel in which sawdust was mixed had a negative effect on the PI of ash.

2. Basicity degree gradually increased, and the PI decreased as the sawdust mixing ratio increased. In addition, in view of the minimal change in the PI depending on the mixing ratio at $32 \%$ or higher, the PI for sewage sludge solid fuel is expected to remain at approximately $60 \%$ at a basicity index of 0.8 or higher.

3. The increase in fluidity when sawdust is added to adjust the basicity is attributed to the melting temperature being lower than that of a single substance if an inorganic material contained in the ash forms a eutectic compound.

4. The slagging rate of the produced slag was $88.03 \%$, and the resulting volume reduction rate was $88.93 \%$, indicating a volume reduction effect on the treatment of sewage sludge in the combustion furnace.

5. Analysis of pollutants in exhaust gases generated by the combustion melting pilot plant operation demonstrated that small amounts of $\mathrm{CO}$ and $\mathrm{SO}_{2}$ were produced. 
However, the average $\mathrm{NO}_{\mathrm{x}}$ concertation was high $(853 \mathrm{ppm})$, indicating that nitrogen was converted to $\mathrm{NO}_{x}$ in the oxygen-rich environment. Therefore, to prevent the release of $\mathrm{NO}_{\mathrm{x}}$, SNCR and SCR facilities need to be installed in oxygen-enriched combustion melting plants when using sewage sludge solid fuel.

6. Analysis of slag containing heavy metals in the eluted solution from sewage sludge solid fuel showed that heavy metals contained in the sewage sludge solid fuel, with the exception of $\mathrm{Cu}$, were retained within the slag. This indicates that heavy metal stability in the environment is ensured in case the sewage sludge solid fuel slag is buried in landfill.

Author Contributions: Conceptualization, D.K. and Y.-S.P.; data curation, D.K., Y.-t.L., S.-n.P. and D.-k.P.; investigation, D.K., Y.-t.L., S.-n.P. and D.-k.P.; writing-original draft preparation, D.K.; writing-review and editing, D.K. and Y.-S.P.; visualization, D.-k.P.; supervision, Y.-S.P.; project administration, K.K.; funding acquisition, K.K. All authors have read and agreed to the published version of the manuscript.

Funding: This study was funded by the "Waste Resource Energy Technology Development Project" of the Ministry of Environment's Korea Environmental Industry and Technology Institute in 2019. (2018001570002).

Institutional Review Board Statement: Not applicable.

Informed Consent Statement: Not applicable.

Data Availability Statement: The data presented in this study are available on request from the corresponding author. The data are not publicly available due to Funding institution's research security pledge.

Conflicts of Interest: The authors declare no conflict of interest.

\section{References}

1. National Sewer Information System. Available online: http:/ /www.hasudoinfo.or.kr (accessed on 5 October 2020).

2. Gao, N.; Kamran, K.; Quan, C.; Williams, P.T. Thermochemical conversion of sewage sludge: A Critical review. Prog. Energy Combust. Sci. 2020, 79, 1-32. [CrossRef]

3. Zhang, Q.; Hu, J.; Lee, D.J.; Chang, Y.; Lee, Y.J. Sludge treatment: Current research trends. Bioresour. Technol. 2017, $243,1159-1172$. [CrossRef] [PubMed]

4. Oladejo, J.; Shi, K.; Luo, X.; Yang, G.; Wu, T. A review of sludge-to-energy recovery methods. Energies 2019, 12, 60. [CrossRef]

5. Electric Power Statistics Information System. Available online: http://epsis.kpx.or.kr (accessed on 5 October 2020).

6. Korean Statistical Information Service. Available online: http:/ / kosis.kr (accessed on 7 October 2020).

7. Wang, Q.; Wei, W.; Gong, Y.; Yu, Q.; Li, Q.; Sun, J.; Yuan, Z. Technologies for reducing sludge production in wastewater treatment plants: State of the art. Sci. Total Environ. 2017, 587-588, 510-521. [CrossRef] [PubMed]

8. Murakami, T.; Ishida, T.; Sasabe, K.; Sasaki, K.; Harada, S. Characteristics of melting process for sewage sludge. Water Sci. Technol. 1991, 23, 2019-2028. [CrossRef]

9. Folgueras, M.B.; Alonso, M.; Folgueras, J.R. Modification of lignite ash fusion temperatures by the addition of different types of sewage sludge. Fuel Process. Technol. 2015, 131, 348-355. [CrossRef]

10. Folgueras, M.B.; Alonso, M.; Folgueras, J.R. Effects of sludge addition to coal on Na, K and S volatilisation in ashing process and ash fusibility. Fuel Process. Technol. 2015, 138, 714-723. [CrossRef]

11. Jeong, B.M.; Kim, D.J.; Park, D.K.; Park, Y.S. A study on characteristics analysis of sludge waste by basicity. J. Korea Soc. Waste Manag. 2019, 36, 567-575. [CrossRef]

12. Park, J.M.; Lee, S.B.; Kim, M.J.; Kim, J.P.; Kim, J.C.; Lee, S.J.; Lee, S.H. Study on the Emission Characteristics of Heavy metals in sewage sludge Incinerator. J. Environ. San. Eng. 2009, 24, 19-27.

13. Zhao, Z.; Wang, R.; Wu, J.; Yin, Q.; Wang, C. Bottom ash characteristics and pollutant emission during the co-combustion of pulverized coal with high mass-percentage sewage sludge. Energy 2019, 171, 809-818. [CrossRef]

14. Yu, T.; Yang, W.; Jeon, K.H.; Shin, D.; Hwang, J.H. Combustion and pyrolysis characteristics of solid wastes in a $30 \mathrm{~kg} / \mathrm{hr}$ capacity pyrolysis melting incinerator. J Korean Soc. Combust. 2006, 32, 172-180.

15. Kong, L.X.; Jin, B.A.I.; Wen, L.I.; Bai, Z.Q.; Guo, Z.X. Effect of lime addition on slag fluidity of coal ash. J. Fuel Chem. Technol. 2011, 39, 407-411. [CrossRef]

16. Kim, M.R.; Kim, K.H.; Sung, H.J.; Kang, D.H.; Park, H.S.; Lee, J.K. Relationship between Basicity and Fluidity in Ash Melting Processes. J. Korea Soc. Waste Manag. 2007, 24, 714-723.

17. Higman, C.; van der Burgt, M. Gasification; Gulf Professional Publishing: Amsterdam, The Netherlands, 2008 ; p. 456. 
18. Yan, T.; Bai, J.; Kong, L.; Li, H.; Wang, Z.; Bai, Z.; Zhao, H.; Li, W. Improved prediction of critical-viscosity temperature by fusion behavior of coal ash. Fuel 2019, 253, 1521-1530. [CrossRef]

19. Watanaba, H.; Shiraishi, T. Improvement of melting temperature and viscosity in sewage sludge melting process. Int. Symp. Environ. Tech. Dev. 1992, 15, 393-404.

20. Park, J.K.; Seo, Y.C. Studies on physicochemical characteristics and optimal melting condition of automobile shredder residue in a melting furnace. Korea Soc. Waste Manag. 2013, 30, 189-198. [CrossRef]

21. Kim, M.R.; Jang, J.G.; Lee, S.K.; Hwnag, B.Y.; Lee, J.K. Correlation between the ash composition and melting temperature of waste incineration residue. Korean J. Chem. Eng. 2010, 27, 1028-1034. [CrossRef]

22. Logachev, G.N.; Gostenin, V.A.; Pishnograevm, S.N.; Seleznev, D.I.; Gridasov, V.P. Mobility of blast-furnace slag. Steel Transl. 2013, 43, 4-6. [CrossRef]

23. Wu, X.; Ji, H.; Dai, B.; Zhang, L. Xinjiang lignite ash slagging and flowability under the weak reducing environment at 1300 ${ }^{\circ} \mathrm{C}$-A new method to quantify slag flow velocity and its correlation with slag properties. Fuel Process. Technol. 2018, 171, 173-182. [CrossRef]

24. American Society for Testing Materials International. ASTM D7582-15 Standard Test Methods for Proximate Analysis of Coal and Coke by Macro Thermogravimetric Analysis; ASTM: West Conshohocken, PA, USA, 2015.

25. Ministry of Environment. Act on The Promotion of Saving and Recycling of Resources; Ministry of Environment: Washington, DC, USA, 2014.

26. United States Environmental Protection Agency. SW-846 Test Method 3052, Microwave Assisted Acid Digestion of Siliceous and Organically Based Matrices; United States Environmental Protection Agency: Washington, DC, USA, 1996.

27. Ministry of Environment. Environmental Testing and Inspection Act; Ministry of Environment: Washington, DC, USA, 2017.

28. United States Environmental Protection Agency. Municipal Solid Waste Combustion Ash Database; United States Environmental Protection Agency: Washington, DC, USA, 1994.

29. Lee, K.H.; Lim, J.H. Investigation of the mixing melting incineration treatment of sewage sludge and municipal solid waste cinder. J. Appl. Chem. 2009, 13, 285-288.

30. Park, H.Y.; Im, H.S.; Kim, E.H.; Kim, Y.J.; Kim, K.S.; Lee, J.E. Advanced slagging propensity of coal and its assessment with the conventional indices. J. Energy Eng. 2012, 21, 427-434. [CrossRef]

31. Guo, L.; Zhai, M.; Wang, Z.; Zhang, Y.; Dong, P. Comprehensive coal quality index for evaluation of coal agglomeration characteristics. Fuel 2018, 231, 379-386. [CrossRef]

32. Namkung, H.; Kim, H.T.; Wang, F.; Lin, K.; Yu, G. Multilateral approaches for investigation of particle stickiness of coal ash at low temperature fouling conditions. Korean J. Chem. Eng. 2017, 34, 3102-3110. [CrossRef]

33. Namkung, H.; Kim, C.H.; Kim, D.; Yuan, X.; Kang, T.J.; Kim, H.T. Effect of bed agglomeration by mineral component with different coal type. J. Energy Inst. 2016, 89, 172-181. [CrossRef] 